\title{
The Role of Tapeworms in Equine Colic
}

\author{
G.B. Edwards \\ Dept. of Veterinary Clinical Science \& Animal Husbandry, University of Liverpool
}

\begin{abstract}
Summary
There is an increasing amount of evidence to incriminate the equine tapeworm Anoplocephala perfoliata in a variety of intestinal obstructions involving the ileum and caecum. Pathological studies have shown that when large numbers of tapeworms cluster together they cause considerable inflammatory changes to the intestinal wall. Until recently the lack of a reliable method of diagnosing tapeworm infections has hampered epidemiological studies but the development of an ELISA serological test which shows a close correlation between optical densities and infection intensity has enabled case control studies to be carried out which show that tapeworms are one of several potential risk factors for colic. Although total elimination of tapeworms is neither realistic nor necessary, identification and treatment of horses with large numbers of tapeworms should reduce the incidence of ileocaecal colic.
\end{abstract}

keywords: $\quad$ tapeworms, Anoplocephala perfoliata, colic, horse

\section{Zur Rolle der Bandwürmer bei der Kolik des Pferdes}

Nach den Ergebnissen jüngerer Untersuchungen mehren sich die Hinweise dafür, dass der Bandwurm Anoplocephala perfoliata an der Entwicklung unterschiedlicher intestinaler Störungen des Pferdes beteiligt ist. Pathologische Untersuchungen zeigen, dass ein starker Bandwurmbefall zu erheblichen entzündlichen Veränderungen der Darmwand führen. Der Mangel an zuverlässigen Nachweismethoden hat bisher eine intensivere epidemiologische Untersuchung verhindert. Seit Einführung eines serologischen ELISA-Tests wurden jedoch kontrollierte Fallstudien möglich, die gezeigt haben, dass Bandwürmer beim Pferd durchaus einen der potentiellen Risikofaktoren für Kolik darstellen. Eine völlige Eliminierung der Bandwürmer bei befallenen Pferden erscheint zwar weder möglich noch notwendig, dennoch kann durch eine Behandlung positiver Patienten Intensität und Häufigkeit der Parasitose vermindert und somit die Gefahr ileozäkaler Koliken reduziert werden.

Schlüsselwörter: Bandwurm, Anoplocephala perfoliata, Kolik, Pferd

\section{Introduction}

Until recently the equine tapeworm Anoplocephala perfoliata was difficult to diagnose and considered to be of questionable pathogenicity by pathologists who regarded its presence in the intestinal tract of horses at post-mortem as incidental. Infection in the live horse usually went undetected because of difficulties associated with coprological diagnosis and because no clearly defined clinical symptoms were associated with it. In the 1980's a number of case reports cited circumstantial evidence suggesting that A. perfoliata was associated with certain 'intestinal accidents' in the horse (Table 1). Ileocaecal obstructions comprised $18.6 \%$ of the last 1000 surgical colic cases at the University of Liverpool (Table 2). Recent studies have defined the pathology caused by this parasite and novel approaches to ante-mortem diagnosis have provided a tool for epidemiological studies.

\section{Prevalence}

Several necropsy studies of the prevalence of tapeworm infection have been reported with prevalence rates varying from $13.6 \%$ to $81.5 \%$ (Table 3 ). No age prevalence has been reported and tapeworm eggs have been identified in the faeces of foals as well as in horses $>30$ years of age. Geographical location, anthelmintic regimens, management and other unknown factors will influence the prevalence rate of any particular population.

\section{Morphology and life cycle}

A. perfoliata is a cestode which has an indirect life cycle via pasture-dwelling oribatid mites. The parasite which has a triangular yellow/green body, matures to an adult in 6-8 weeks in the intestine of the horse, and attains a final size of only $5-8 \mathrm{~cm}$ in length. It has a predilection for the ileocaecal region where it attaches to the mucosa by means of 4 suckers on the scolex. The cuticle and lappets have intense enzymatic activity associated with food uptake which takes place by absorption through the cuticle. Adult parasites shed gravid proglottids which break up during passage through the large intestine. Within the mite the embryonated egg develops to a cysticercoid larva, a process which takes 12-15 weeks. Inadvertent ingestion of these mites will establish tapeworm infection in grazing horses.

\section{Pathogenesis}

Until recently few studies of the pathological changes induced by A. perfoliata have been published. Pathological studies have identified both gross and histological pathology at the site of parasite attachments, the severity being directly proportional to parasite infection intensity (Beroza et al. 1986; Fogarty et al. 1994; Pearson et al. 1993). A survey carried out at an abattoir in Ireland (Fogarty et al. 1994) showed that $51 \%$ of horses examined had tapeworms attached to the mucosa at the ileo-caecal junction and/or the 
caecum. Of these $5 \%$ were only at the ileocaecal junction, $24 \%$ only to the caecal mucosa and $22 \%$ at both sites. In this survey and that reported by Pearson et al. (1993), the number of tapeworms present varied considerably and only a few horses had heavy burdens. The extent of the infestation was not related to breed, age or source of origin of the horses. When large numbers of tapeworms are present they are attached in clusters. This effect appears to be mediated by a pheromone (Bone et al. 1980) and may be reduced by the host's immune mechanisms (Roberts and Thorson 1977). The parasite is non-migrating in the final host so that the pathological effects are limited to the intestine and, more specially, to the sites of attachment. Horses with 1-20 tapeworms show only relatively mild changes varying from superficial mucosal congestion to focal ulceration and diphtheresis. Occasionally there is some involvement of the submucosa.

Tab 1: Intestinal accidents attributed to A. perfoliata

A. perfoliata zugerechnete gastrointestinale Störungen

\begin{tabular}{|l|l|}
\hline Intussusceptions & $\begin{array}{l}\text { Barclay et al. 1982; Beroza et al. 1986; } \\
\text { Cosgrove et al. 1986; Edwards 1986 a \& } \\
\text { b; Owen et al. 1989; Gaughan 1990 }\end{array}$ \\
\hline $\begin{array}{l}\text { Ileal hypertrophy } \\
\text { and perforation }\end{array}$ & Bello 1979; Edwards 1986 \\
\hline Caecal perforation & Beroza et al. 1983; 1986 \\
\hline Caecal torsion & Beroza 1986 \\
\hline $\begin{array}{l}\text { Caecal mucosal } \\
\text { hypertrophy }\end{array}$ & Edwards 1986b \\
\hline
\end{tabular}

In contrast in horses with 21 to $100+$ tapeworms there is always ulceration from the superficial mucosa to the submucosa with accompanying focal mucosal haemorrhage and diphtheresis consisting of inflammatory cell exudate. Submucosal oedema is present and there is infiltration of the mucosa, lamina propria and submucosa with large numbers of eosinophils and lymphocytes (Pearson et al. 1993). Fibrosis, when present, disrupts the tissue architec-

\begin{tabular}{|l|c|}
\hline Ileal Conditions & \\
\hline lleal impaction & 62 \\
lleal hypertrophy & 27 \\
Ileal perforation & 3 \\
\hline \hline Intussusceptions & \\
\hline Ileo-ileal & 8 \\
Ileo-caecal & 23 \\
Caeco caecal & 23 \\
Caeco colic & 20 \\
\hline \hline Caecal Conditions & \\
\hline Caecal rupture & 15 \\
Mucosal hypertrophy & 5 \\
(at ileo caecal junction) & \\
\hline
\end{tabular}

Obstruction involving ileo-caecal region in 1000 surgical colic cases $(n=186)$

Obtruktionen im ileozäkalen Bereich auf 1000 chirurgische Kolikfälle $(n=186)$ ture and occasionally there is abscessation of the mucosa at the ileocaecal junction. Clustering of tapeworm attachments exacerbates the local lesions and the inflammatory responses extend beyond the area of the lesion. The mechanisms by which the pathology arises remain uncertain but it is reasonable to implicate parasite-derived antigens in the process. With extension into the submucosa there is a greater potential to disrupt the vascular supply and nervous regulation. By interfering with such mechanisms and by altering the thickness of the bowel wall at the ileocaecal junction, A. perfoliata infestation satisfies some of the criteria necessary to cause disturbed bowel motility. The precise way in which tapeworms initiate intussusception is not clear. Reymond (1972) analysed potential causes of intussusception and found two common factors. One was local change in bowel wall such as an indurated area, or abrupt change in bowel diameter; the other was an extra or intra luminal linkage of two segments of bowel. The ulceration, oedema and granulation tissue caused by tapeworms at their attachments are consistent with Reymond's model. The preferential attachment of tapeworms to the ileocaecal orifice, an area of abrupt change in bowel diameter is also consistent with the model (Barclay et al. 1982). Muscular hypertrophy of the ileum caused by tapeworm damage results in recurrent colic over a few weeks, the bouts becoming more frequent and more severe with the passage of time. The hypertrophy may be accompanied by several small diverticuli which appear as soft, fluctuating depressions in the wall of the ileum (Fig. 1) possibly initiated by mucosal ulceration. Perforation of the paper-thin wall of one of these diverticuli which comprises only serosa and a thin layer of chronic inflammatory tissue, can lead to fatal generalised peritonitis.

Some cases are found to have a marked swelling of the caecal mucosa at the ileocaecal orifice producing a doughnut-like ring (Fig. 2) which is palpable at laparotomy through the caecal wall. Horses with this type of lesion show sudden onset of moderately severe pain with progressive distension of the small intestine over a period of 12-24 hours. Submucosal oedema is the major feature of the doughnutlike lesion and is the likely cause of the rapidly developing

Tab 3: Prevalence of tapeworm infection Prävalenz des Bandwurmbefalls

\begin{tabular}{|l|c|l|}
\hline & $\begin{array}{c}\% \text { of } \\
\text { population }\end{array}$ & Reference \\
\hline London area & 31 & Imrie and Jacobs 1987 \\
\hline Wales & 69 & Owen et al. 1988 \\
\hline Kentucky & 53 & Lyons et al. 1983 \\
\hline Minnesota & 54 & Olsen 1938 \\
\hline South Auckland, N.Z. & 82 & Bain and Kelly 1977 \\
\hline Canada & 14 & Slocombe 1979 \\
\hline Sweden & 65 & Nilsson et al. 1995 \\
\hline
\end{tabular}


complete obstruction of the orifice. The obstruction can be by-passed successfully by means of a side-to-side ileocaecal anastomosis without resection.

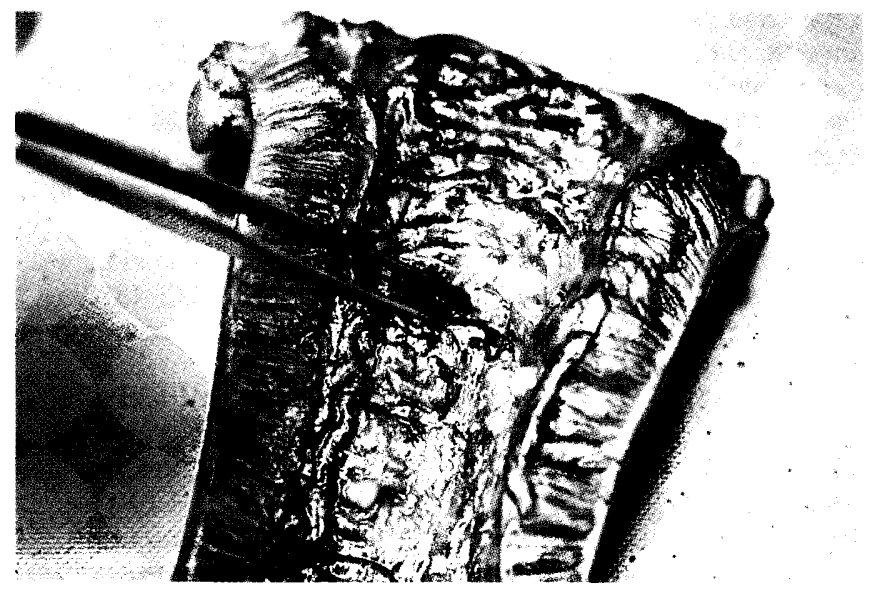

Fig.1: Terminal ileum showing gross thickening of its wall and several diverticuli.

Terminales lleum mit Wandverdickung und mehreren kleinen Divertikeln.

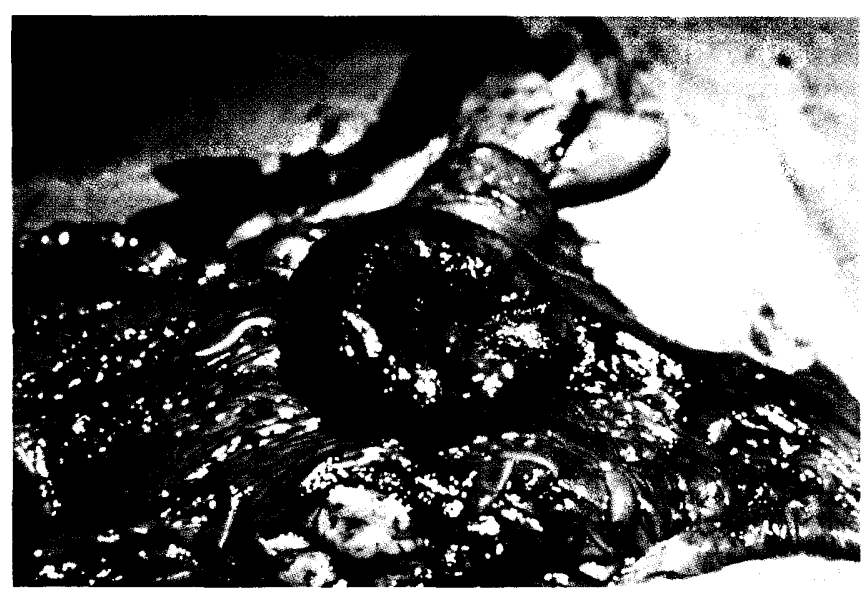

Fig. 2: Marked thickening of the caecal mucosa at the ileocaecal junction causing obstruction.

Umschriebene Verdickung der Zäkummukosa im Bereich der ileozäkalen Verbindung

\section{Evidence to implicate A. perfoliata in ileocaecal colic}

Clinically based evidence is insufficient to unequivocally implicate A. perfoliata in ileocaecal colic. Epidemiological studies were hampered by the fact that examination of faeces for eggs is an inadequate method of diagnosing cestodiasis. Although the eggs are very characteristic in appearance, unfortunately they are present in very small numbers in the faeces of infected horses. Validation of the centrifugal flotation technique by examination of faeces from 80 horses with known numbers of tapeworms, examined at an abattoir, gave a sensitivity of $61 \%$ and a specificity of $98 \%$. If negative results in horses with less than 20 tapeworms were excluded the sensitivity was increased to 92\% (Proudman and Edwards 1994). No correlation was found between the number of eggs found in the faeces and the number of tapeworms found in the intestine.
A case-control study using this coprological diagnosis showed an association between A. perfoliata infestation and ileocaecal colic but the information was limited by low diagnostic sensitivity (Proudman and Edwards 1993). No association was found between colic of all types and tapeworms but comparison of odds ratios for horses with +ve faeces which had ileocaecal colic and those with small intestinal lesions and large intestinal obstruction did show a significant difference (Table 4). Odds ratio of $>1$ implies an increased risk of colic of ileocaecal origin in horses with tapeworms. Proudman and Edwards (1993)

Tab 4: Odds ratio, calculated attributable risk $=0.24$ (24 cases for 100)

Zuordnung, geschätztes Risiko $=0.24$ (24 Fälle auf 100 Pferde)

\begin{tabular}{|l|c|c|c|c|}
\hline Colic origin & +ve & -ve & O.R. & 95\% confidence \\
\hline Small intestine & 6 & 20 & 0.64 & $0.84-1.58$ \\
Ileocaecal & 10 & 10 & 3.45 & $1.18-5.18$ \\
Large intestine & 8 & 28 & 0.53 & $0.37-1.29$ \\
\hline
\end{tabular}

The need for an improved diagnostic method has led to the development of a successful ELISA utilising the host's $\operatorname{lgG}(7)$ response to a $12 / 13 \mathrm{kDa}$ protein secreted by the parasite for the serological diagnosis of tapeworm infestation in horses (Proudman and Trees). Although the ELISA only showed a slight improvement in overall sensitivity (68\%) compared to the coprological techniques, it shows a good correlation between ELISA optical density values and infection intensity. Therefore the assay is extremely useful clinically because it enables those horses at greatest risk of developing ileocaecal colic, i.e. those with significant $(20+)$ tapeworms to be identified. It has also offered a unique opportunity to conduct other case-control studies. Proudman, French and Trees (1998) used the assay together with conventional coprological diagnosis to evaluate tapeworm infection as a risk factor for ileal impaction colic (as diagnosed at laparotomy) and spasmodic colic in a matched case-control study. Twenty ileal impaction cases each with two controls matched for age, breed and gender, and 100 spasmodic colic cases with an equal number of similarly matched controls, were obtained. For cases of ileal impaction, a strong association was found between colic and $\mathrm{A}$. perfoliata as diagnosed by coprological means (odds ratio of 34.0). Serological diagnosis also revealed a strong association that increased with higher levels of infection intensity (odds ratio $=26.0$ ). The calculation of an aetiological fraction suggests that $91 \%$ of ileal impaction cases in this study were tapeworm associated. Cases of spasmodic colic were also much more likely (odds ratio $=8.0$ ) to be associated with A. perfoliata infection detected coprologically than controls. Serological diagnosis revealed an increasing risk of spasmodic colic with increasing infection intensity. The aetiological fraction for the spasmodic colic data suggested that $22 \%$ of the cases in this study were tapeworm associated. The authors concluded that A. perfoliata is a signifi- 
cant risk factor for spasmodic colic and ileal impaction in the horse and that the risk of spasmodic colic increases with infection intensity.

The ELISA assay has also been used to carry out a field investigation of an abnormally high incidence of colic including several cases of ileal impaction in a yard containing 75 Arabs and Thoroughbreds used for flat-racing (Proudman and Holdstock 1998). An age-stratified analysis gave a summary odds ratio of 44 for the risk of colic in the presence of tapeworm infection. Following administration of anticestode anthelmintics to all horses and the introduction of a prophylactic regimen, the incidence of colic fell to a consistently lower level over the next 15 months from the previous peak quarterly incidence of 1.15 colic episodes per horse year at risk.

\section{Conclusion}

It seems probable that a number of different risk factors can act singly or in concert and lead to intestinal dysfunction resulting in the clinical syndrome of 'colic'. Infestation with A. perfoliata would appear to be one of these factors but, like other risk factors, may show regional variation. The relationship between tapeworm infection intensity and colic is supported by the work of Fogarty et al. (1994), Pearson et al. (1993) and Nilsson et al. (1995) who showed that ileocaecal pathology is proportional to infection intensity.

Elimination of tapeworms is probably unrealistic and unnecessary. Control measures should be aimed at minimising the number of horses with moderate/high infection intensities which are at greatest risk of developing tapeworm-related colic by regular treatment with pyrantel or praziquantel at appropriate doses. The ELISA assay can be useful in the investigation of single or recurrent colic cases. Once identified, horses with high infection intensities can be treated. The outcome of these recent studies warrants an intervention study to confirm that control of the parasite does result in a reduction in the incidence of colic.

\section{Literature}

Bain, S.A. and Kelly, J.D. (1977): Prevalence and pathogenicity of Anoplocephala perfoliata in a horse population in South Auckland. New Zealand Vet. J. 25, 27-28

Barclay, W.P., Philips, T.N. and Foerner, J.J. (1982): intussusception associated with Anoplocephala perfoliata infection in 5 horses. J. Am. Vet. Med. Ass. 180, 752-753

Bello, T.R. (1979): Perspectives on current anthelmintic therapy: Misunderstandings and classification. Proc. Am. Ass. of Equine Pract. 25, 261-265

Beroza, G.A., Barclay, W.P., Philips, T.N., Foerner, J.J. and Donawick, W.J. (1983): Caecal perforation and peritonitis associated with Anoplocephala perfoliata infection in 3 horses. J. Am. Vet. Med. Ass. 183, 804-806

Beroza, G.A., Williams, R., Marcus, L.C. and Mille, P. (1986): Prevalence of tapeworm infection and association with large bowel disease in horses. Proc. 2nd Equine Colic Research Symposium. Athens, Georgia. pp. 21-25
Cosgrove, J.S., Sheeran, J.J. and Sainty, T.J. (1996): Intussusception associated with Anoplocephala perfoliata in a 2 year old Thoroughbred. Ir. Vet. J. 40, 35-36

Edwards, G.B. (1986a): Surgical management of intussusception in the horse. Equine Vet. J. 18, 313-321

Edwards, G.B. (1986b): Intestinal disease associated with Anoplocephala perfoliata in the horse. Proc. of the 16th Congress of European Soc. of Vet. Surg. Sept. 21-23, 1986. London. pp. 99-105

Fogarty, V., Delfiero F., Purnell, R.E. and Mosurski, K.R. (1994): Incidence of Anoplocephala perfoliata in horses examined at an Irish abattoir. Vet. Rec. 134, 515-518

Gaughan, E.M. and Hackett, R.P. (1990): Intussusception in horses: 11 cases (1978-1989). J. Am. Vet. Med. Ass. 197, 1373-1375

Imrie H. and Jacobs, D.E. (1987): Prevalence of horse tapeworm in North London and Hertfordshire. Vet. Rec. 120, 340

Lyons, E.T., Tolliver, S.C., Drudge, J.H., Swerczek, T.W. and Crowe, M.W. (1983): Parasites in Kentucky Thoroughbreds at necropsy. Emphasis on stomach worms and tapeworms. Am. J; Vet. Res. 44, 839-844

Nilsson, O., Lungstrom, B.L., Hoglund, J., Lunquist, H. and Uggla, A. (1995): Anoplocephala perfoliata in horses in Sweden. Prevalence, infection levels and intestinal lesions. Acta Vet. Scand. 36, 319-328

Olsen, O.W. (1938): Anoplocephalosis in Minnesota horses. J. Am. Vet. Med. Ass. 92, 557-559

Owen, R ap R., Jagger, D.W. and Quan-Taylor, R. (1988): Prevalence of Anoplocephala perfoliata in horses and ponies in Clwyd, Powys and adjacent English Marches. Vet. Rec. 123, 562-563

Owen R ap R., Jagger, D.W. and Quan-Taylor, R. (1989): Caecal intussusception in horses and the significance of Anoplocephala perfoliata. Vet. Rec. 124, 34-37

Pearson, G.R., Davies, L.W., White, A.L. and O' Brien, J.K. (1993): Pathological lesions associated with Anoplocephala perfoliata at the ileocaecal junction in horses. Vet. Rec. 132, 179-182

Proudman, C.J. and Edwards, G.B. (1992): Validation of a centrifugal flotation technique for the diagnosis of equine cestodiasis. Vet. Rec. 131, 71-72

Proudman, C.J. and Edwards, G.B. (1993): Are tapeworms associated with equine colic? A case control study. Equine Vet. J. 25, 224-226

Proudman, C.J. and Trees, A.J. (1996a): Use of excretory/secretory antigens for the serodiagnosis of Anoplocephala perfoliata. Vet. Parasitol. 61, 239-247

Proudman, C.J., French, N.P. and Trees, A.J. (1998): Tapeworm infection is a significant risk factor for spasmodic colic and ileal impaction colic in the horse. Equine Vet. J. 30, 194-199

Proudman, C.J. and Holdstock, N.B. (1998): Investigation of an outbreak of tapeworm-associated colic in a Training Yard. Abstract. 6th Colic Research Symposium. Athens, Georgia. p.26

Reymond, R.D. (1972): A mechanism for intussusception: A theoreti$\mathrm{Cal}$ analysis of the phenomenon. $\mathrm{Br}$. J. Radiol. 45, 1-7

Roberts, T.M. and Thorsen, R.E. (1977): J. Parasitolgy 63, 357

Slocombe, J.O.D. (1979): Prevalence and treatment of tapeworms in horses. Can. Vet J. 20, 136-140

Vortrag anläßlich der 13. Equitana-Fachtagung für Pferdekrankheiten, Essen, 12.-13. März 1999

\section{Prof. G.B. Edwards}

Faculty of Veterinary Science

The University of Liverpool

Leahurst, Neston

UK South Wirral L64 7TE

Tel.: 00441517946073

Fax: 00441517946034 